\title{
IPTEKS SISTEM AKUNTANSI INSTANSI BERBASIS AKRUAL (SAIBA) DALAM PENYAJIAN LAPORAN KEUANGAN PADA LEMBAGA PENJAMINAN MUTU PENDIDIKAN PROVINSI SULAWESI UTARA
}

\author{
Patrycia Marcellina Maria Tampemawa ${ }^{1}$, Wulan D. Kindangen ${ }^{2}$ \\ 1,2,Jurusan Akuntansi,Fakultas Ekonomi dan Bisnis Universitas Sam Ratulangi, Jl. Kampus Unsrat, Manado, \\ 95115, Indonesia \\ E-mail: patryciapetty@gmail.com
}

\begin{abstract}
The institute of Educational Quality Assurance is a government agency engaged in education, which aims to ensure that standards, norms, criteria and procedures set by the central government in accordance with the implementation of education in North Sulawesi. In this agency all the parts that have to be able to run well to realize good governance, one of which the finance department whose job is to present financial statements. The application of accrual-based accounting in the central or regional government is supported by the existence of the SAIBA application, so that the presentation of financial statements, one of which is the financial report at LPMP, assisted by the application of SAIBA. Referring to PMK 270 / PMK.05 /2014 wherein it has been equipped with an Operational Report, Equity Change Report, where in the previous system only issued two types of reports, that is Budget Realization Report and Report form Balance Sheet. The financial statements must be appended with the Financial Statement notes for annual report.
\end{abstract}

Keyword: Financial statements, Accrual Basis, SAIBA

\section{PENDAHULUAN}

Untuk dapat merealisasikan pemerintahan yang baik (good governance) membutuhkan upaya-upaya untuk menjadi lebih akuntabilitas dan tranparansi dalam penyelenggaraan pemerintahan. Untuk dapat mewujudkan hal tersebut maka perlu di susun kebijakan-kebijakan dan peraturan perundang-undangan untuk memperkuat sistem, standar, dan sumber daya aparatur dan kelembagaan. Salah satu upaya yang dilakukan untuk membuat tata kelola keuangan yang baik adalah dengan adanya Standar Akuntansi Pemerintah (SAP). Namun penerapan SAP berbasis kas menuju akrual masih bersifat sementara, dan kemudian pada tahun 2010 komitmen untuk akrual penuh ditunjukkan dalam PP No 71 tahun 2010 tentang Standar Akuntansi Pemerintah sebagai pengganti PP No 24 tahun 2005. SAP tersebut kemudian dinyatakan dalam bentuk Pernyataan Standar Akuntansi Pemerintah (PSAP) yang di dalamnya di lengkapi dengan Pengantar Standar Akntansi Pemerintahan yang di susun berarah pada Kerangka Konseptual Akuntansi Pemerintahan.

SAP yang berbasis akrual juga mengakui beberapa hal yaitu, asset, beban, utang, pendapatan, dan ekuitas dalam pelaporan keuangan berbasis akrual, dan juga megakui belanja, pendapatan, dan pembiayaan dalam pelaporan pelaksanaan anggaran berdasarkan basis yang ditetapkan dalam APBD/APBN. Untuk membantu penerapan SAP kas berbasis akrual maka pemerintah pusat meggunakan sistem aplikasi terintegrasi, yang dimaksud dengan sistem tersebut ialah mengintegrasi seluruh proses penganggaran, pelaksanaan, dan pelaporan pada Bendahara Umum Negara dan Kementerian Negara/Lembaga terkait dengan pengelolaan APBN. Dijelaskan dalam PMK 270/PMK.05/2014 pasal 5 ayat (1) bahwa laporan keuangan berbasis akrual disusun menggunakan aplikasi Sistem Akuntasi Instansi Berbasis Akrual (SAIBA). Terkait dengan pengelolaan keuangan sampai dengan penyajian laporan keuangan, Lembaga Penjaminan Mutu Pendidikan Provinsi Sulawesi Utara 
memanfaatkan aplikasi SAIBA di dalamnya. Aplikasi ini mempermudah dalam pengelolaan dan penyajian laporan keuangan yang ada di LPMP sehingga dapat menghasilkan laporan keuangan yang berbasis akrual di mana di dalamnya telah dilengkapi dengan Laporan Operasional, dan Laporan Realisasi Anggaran, serta pada pelaporan tahunan dilengkapi dengan Catatan Atas Laporan Keuangan (CALK).

\section{TINJAUAN PUSTAKA}

Sistem Akuntansi Instansi Berbasis Akrual (SAIBA). Sistem akuntansi instansi berbasis akrual sepenuhnya diterapkan pada tahun 2015, dimana pada tahun sebelumnya yang di terapkan adalah sistem kas menuju akrual. Hal tersebut diamanatkan pada Undang-Undang Keuangan Negara bahwa pada setiap instansi pemerintahan sudah harus menerapkan sistem akuntansi berbasis akrual. Sistem akuntansi dan penyusunan laporan keuangan akrual pada satuan kerja didukung dengan adanya aplikasi SAIBA. Perubahan - perubahan yang terdapat dalam SAIBA meliputi pencatatan transaksi, migrasi saldo, serta penyesuaian-penyesuaian. Sistem akuntansi instansi berbasis akrual (SAIBA) merupakan modifikasi dari sistem akuntansi kuasa pengguna anggaran (SAKPA) dimana pengoperasiaannya sama, di dalamnya mecakup perekaman dokumen manual ataupun elektronik, posting pada buku besar, dan penyusunan laporan keuangan.

Laporan Keuangan. Laporan keuangan menurut IAI (2015:5) merupakan laporan penggamabaran dari kondisi keuangan kegiatan hasil usaha suatu perusahan pada waktu atau saat tertentu. Laporan keuangan juga berguna untuk dapat mengetahui kinerja dari suatu perusahaan apakah keuangan persuhaan tersebut dalam kondisi yang baik atau tidak, serta dapat digunakan untuk membantu dalam pengambilan keputusan. Laporan keuangan yang baik terdapat hal-hal berikut, seperti relevan, dapat dipahami, dapat dipercaya, dapat di uji, dan dapat dibandingkan. Pada umumnya laporan keuangan mencakup, laporan laba atau rugi, neraca, laporan arus kas, laporan perubahan ekuitas, dan catatan atas laporan keuangan.

\section{METODE DAN TEKNIK PENERAPAN IPTTEKS}

\subsection{Metode Penerapan Ipteks}

Metode ipteks yang dipakai adalah deskriptif dari data-data yang diperoleh melalui hasil wawancara pada Lembaga Penjaminan Mutu Pendidikan.

\subsection{Teknik Penerapan Ipteks}

Teknik ipteks yang dipakai adalah dengan mengumpulkan data tentang sistem akuntansi instansi berbasis akrual serta penyajian laporan keuangan menggunakan aplikasi SAIBA dan data tersebut dianalisis.

\section{PEMBAHASAN}

\subsection{Gambaran Objek Penerapan Ipteks}

Lembaga Penjaminan Mutu Pendidikan (LPMP) Sulawesi Utara merupakan instansi yang bergerak di bidang pendidikan. LPMP merupakan hasil resturkturisasi dan refungsionalisasi BPG Manado. Pembentukan LPMP Sulawesi Utara mempunyai tujuan agar pelaksanaan pendidikan di Sulawesi Utara dapat sesuai dengan norma, kriteria, standar, serta prosedur yang sudah ditetapkan oleh pemerintah pusat. LPMP Sulawesi Utara merupakan unit pelaksana teknis (UPT) pusat di dalam lingkungan Depdiknas dimana dalam pelaksanaan dari kegiatannya secara teknis terkoordinasi dan dikoordinasi oleh Dirjen PMPTK. Dalam pelaksanaan tugasnya, LPMP menyelenggarakan fungsi pemetaan, pengembangan dan pengelolaan sistem informasi pendidikan dan menengah, supervisi satuan, fasilitas peningkatan, pelaksanaan kerja sama dibidang penjaminan mutu pendidikan, dan pelaksanaan urusan adminitrasi LPMP. 


\subsection{Pembahasan}

Berdasarkan data yang sudah di dapatkan dan di analisis untuk penerapan aplikasi sistem akuntansi berbasis akrual (SAIBA) pada Lembaga Penjaminan Mutu Pendidikan Sulawesi Utara yang sudah menerapkan PMK 270/ PMK.05/2014 untuk menyajikan laporan keuangan berbasis akrual dengan bantuan SAIBA serta untuk penyajian laporan keuangan menggunakan SAIBA di LPMP SULUT memberikan beberapa kelebihan dibandingkan dengan menggunakan aplikasi sistem akuntansi yang ada sebelumnya. Kelebihan tersebut antara lain :

1. Dapat meminimalisir adanya human error. Aplikasi SAIBA merupakan modifikasi dari aplikasi sebelumnya, oleh karena itu ini dapat membuat transaksi yang terjadi dan diakui semakin tinggi dan semakin kompleks, hal tersebut dapat menjadi resiko dalam penginputan data manual karena dapat terjadi kesalahan dalam pengetikan dan klasifikasi. Dengan adanya SAIBA kesalahan tersebut bisa diminimalisir karena dalam penginputan data oleh operator tidak perlu menginput sedemikian banyak data yang nantinya bisa menimbulkan resiko kesalahan. Dalam pemrosesan informasi dapat menggunakan data dari aplikasi lain dan juga tetap dapat melakukan input manual untuk transaksi-transaksi tertentu sehingga menghasilkan keakuratan serta keandalan informasi yang tinggi.

2. Proses yang cepat dalam pelaporan dan pengolahan. Adanya aplikasi SAIBA membantu mempercepat dan mempermudah proses dari perekaman, pengolahan dan pelaporan yang dulunya pada aplikasi sebelumnya membutuhkan waktu yang lama. Dengan hal tersebut informasi yang diperlukan juga dapat didapatkan dengan segera, sehingga dapat berguna dalam bahan petimbangan untuk mengambil keputusan. Karena dalam bisnis peluang emas yang seharusnya dapat diraih dapat hilang karena keterlambatan.

3. Keamanan data yang tinggi. Aplikasi SAIBA hanya dapat memberikan aksesnya kepada orang-orang yang mempunyai otoritas khusus terhadap aplikasi ini, sehingga keamanan dan kerahasiaan data dapat terjamin.

\section{KESIMPULAN DAN SARAN}

\subsection{Kesimpulan}

Dengan adanya aplikasi Sistem Akuntansi Instansi Berbasis Akrual (SAIBA) ini penyajian laporan keuangan pada Lembaga Penjaminan Mutu Pendidikan Sulawesi Utara dapat tersaji dengan baik sesuai dengan PMK 270/ PMK.05/2014 untuk dapat menyajikan laporan keuangan berbasis akrual, dan juga dari penggunaan aplikasi tersebut didapatkan beberapa kelebihan dibandingankan dengan menggunakan aplikasi yang sudah ada sebelumnya.

\subsection{Saran}

Perlunya dilakukan pelatihan bagi operator aplikasi sehingga dapat menjalankan aplikasi dengan baik secara efektif dan efisien.

\section{DAFTAR PUSTAKA}

Herwiyanti, Sukirman dan Aziz. 2017. "Analisis Implementasi Akuntansi Berbasis Akrual pada Inspektorat Jenderal Kementerian Keuangan”. Jurnal Akuntansi dan Keuangan Vol.19 No.1

IAI. 2009. Standar Akuntansi Keuangan. Jakarta: Salemba Empat.

IAI. 2015. Laporan Keuangan. Jakarta: Salemba Empat

Kementerian Keuangan Republik Indonesia. 2014. Peraturan Menteri Keuangan Republik Indonesia Nomor 270/PMK.05/2014 tentang Penerapan Standar Akuntansi Pemerintahan Berbasis Akrual Pada Pemerintah Pusat 
Kristiawati. 2015. "Faktor- Faktor Yang Mempengaruhi Keberhasilan Penerapan Akuntansi Berbasis Akrual Pada Pemerintah Daerah Kalimantan Barat" Jurnal Akuntabilitas Vol. VIII No.3

Kusuma. 2013. "Analisis Faktor-Faktor Yang Mempengaruhi Tingkat Penerapan Akuntansi Akrual Pada Pemerintah". Skripsi. Fakultas Ekonomika dan Bisnis Diponegoro : Semarang

Mahardini, Miranti. 2018. "Dampak Penerapan Standar Akuntansi Pemerintahan dan Kompetensi Sumber Daya Manusia pada Kualitaas Laporan Keuangan Pemerintah Provinsi Banten Tahun Anggaran 2015" . Jurnal Akuntansi Vol. 5 No.1

Mahsun, Sulistyowati dan Purwanugraha. 2006. Akuntansi Sektor Publik. Yogyakarta : BPFE - Yogyakarta

Peraturan Pemerintah Republik Indonesia. 2010. Peraturan Pemerintah Republik Indonesia Nomor 71 Tahun 2010 tentang Standar Akuntansi Pemerintah

Peraturan Pemerintah Republik Indonesia. 2005. Peraturan Pemerintah Republik Indonesia Nomor 24 Tahun 2005 tentang Standar Akuntansi Pemerintah

Suhaeti, Suhendar. 2015. "Pengaruh Implementasi Standar Akuntansi Pemerintahan (SAP) dan Sistem Pengendalian Intern Pemerintah (SPIP) terhadap Kualitas Laporan Keuangan pada Pemerintahan Daerah Kabupaten Kuningan”. Jurnal Riset Keuangan dan Akuntansi Vol.1 No.02

Suryanto. 2017. "Tinjauan Implementasi Akuntansi Pemerintahan Berbasis Akrual di Indonesia”. Jurnal AdBispreneur Vol.2 No.3

Zawitri, Kurniasih dan Kartikawati. 2015. "Penerapan Sistem Akuntansi Instansi Berbasis Akrual Sebagai Implementasi PP No. 71 Tahun 2010 pada Politeknik Negeri Pontianak" Jurnal Ekonomi Bisnis dan Kewirausahaan Vol. 4 No.1 